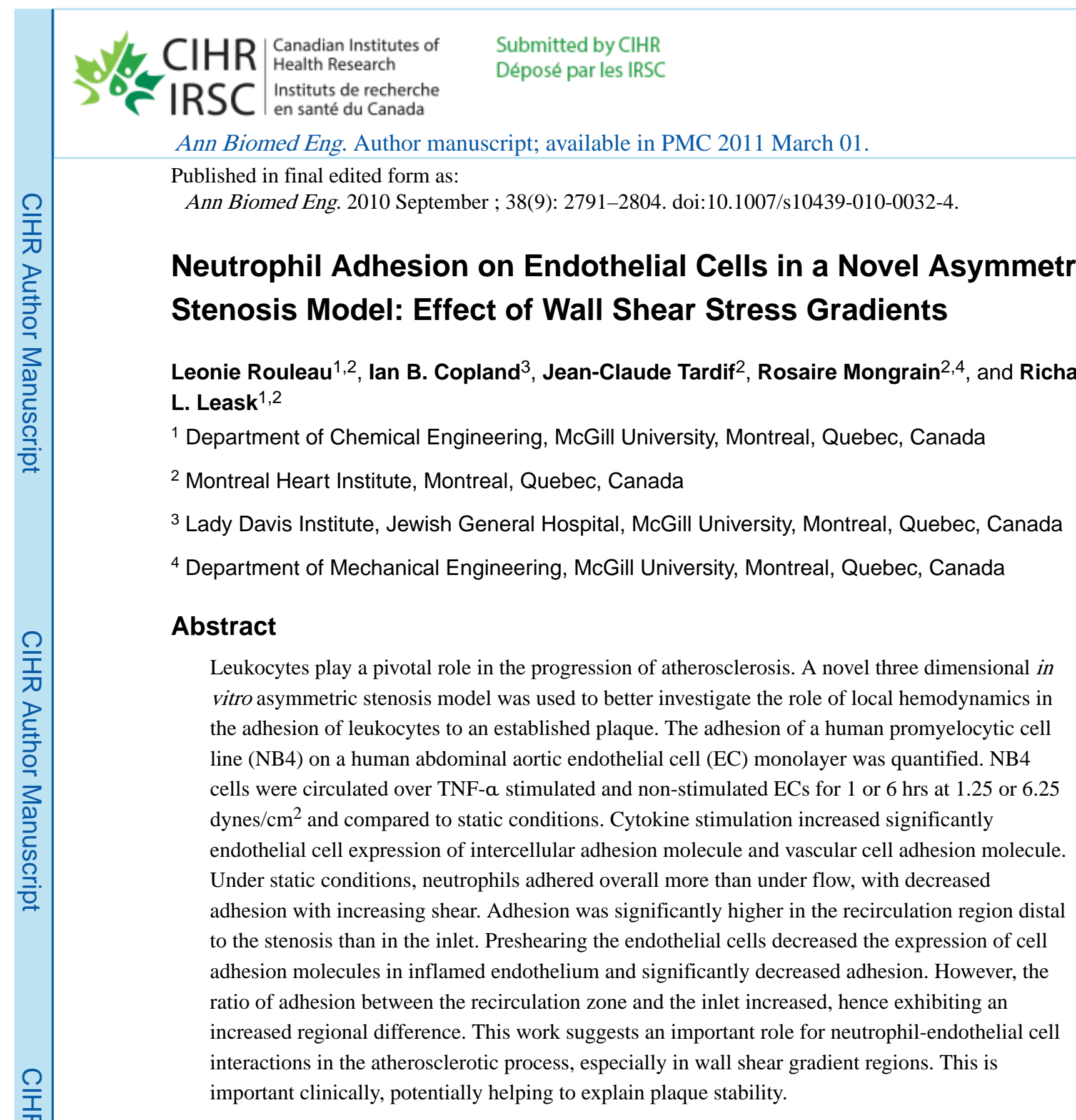

\title{
Key terms
}

in vitro perfusion; wall shear stress; coronary plaque; inflammation; vulnerability; stability

\section{Introduction}

Inflammation plays a pivotal role in the initiation and progression of atherosclerotic lesions. There is substantial evidence that shows the involvement of inflammatory pathways in the pathogenesis of atherosclerosis (1-3). In established plaques, inflammatory cell recruitment

Corresponding author: Richard L. Leask, Department of Chemical Engineering, McGill University, 3610 University St., Montreal, Québec, H3A 2B2, Canada, Phone: (514) 398 4270, richard.leask@mcgill.ca.

Conflict of Interest: none declared. 
produces various enzymes, activators and inhibitors which can destabilize the fibrous cap $(4,5)$. Post mortem studies have shown an accumulation of inflammatory cells in the shoulder regions of ruptured coronary plaques $(6,7)$.

The local response of endothelial cells (ECs) to hemodynamic forces is hypothesized to cause the predilection of atherosclerosis in regions of complex blood flow, such as bifurcations, branches and curvature $(8,9)$. In vitro studies have confirmed the ability of ECs to alter their phenotype in response to fluid shear stress into a pro-inflammatory or proatherogenic phenotype $(10,11)$. The recruitment and attachment of leukocyte to the endothelium is dependent on the cell phenotype and the local fluid forces acting on the circulating leukocyte $(12,13)$. The local response of the endothelial cells and the complex hemodynamics created by the geometry of a stenosis likely plays a role in the regional attachment of leukocytes. Incorporation of leukocytes into the vessel wall follows a complex sequence of events which includes the tethering and rolling of the leukocytes along the endothelial cell surface, attachment to the endothelial cells and transmigration through the endothelial layer into the vessel wall $(14,15)$. This is a very dynamic process and one that needs to be understood in the context of coronary stenosis and plaque stability.

To better understand the role of hemodynamics in the local recruitment of leukocytes to an established coronary plaque, we have developed a novel three dimensional in vitro asymmetric stenosis cell culture model. The results show local increases in cell adhesion in regions of spatial wall shear stress gradients and a dependency on the mean entrance wall shear stress, adhesion assay duration and endothelial cell phenotype.

\section{Methods}

\section{Cell cultures}

The interaction of an acute promyelocytic leukaemia cell line (NB4 cells) with human abdominal aortic endothelial cells (HAAECs) was investigated in a three dimensional cell culture model. NB4 cells were maintained in suspension culture at $2 \times 10^{5}-1 \times 10^{6}$ cells $/ \mathrm{mL}$ in RPMI 1640 medium with 2 mM L-glutamine (Hyclone, SH3002701), supplemented with $10 \%$ heat-inactivated fetal bovine serum (Invitrogen, 26140-079) and 1\% penicillin streptomycin (Invitrogen, 15140-122). For differentiation into granulocytes, cells were stimulated for $48 \mathrm{hrs}$ in the presence of $10^{-6} \mathrm{M}$ all-trans-retinoic acid (ATRA) (Sigma $\mathrm{R} 2625)$, diluted in cell culture media from a stock of $10^{-4} \mathrm{M}$ in DMSO, prior to the adhesion assays. Cell viability was assessed using the trypan blue dye exclusion test (Invitrogen, 15250-061).

Human abdominal aortic endothelial cells (HAAECs) derived from a 20 year old male were purchased from ATCC (American Type Culture Collection, CRL-2472) and expanded up to fifth passages. Flasks were coated with $0.1 \%$ pig gelatin (Sigma-Aldrich, G2500), and cells cultured in endothelial cell growth media (Promocell, C-22010, C-39215), 10\% fetal bovine serum (Invitrogen, 26140-079) and 1\% penicillin streptomycin (Invitrogen, 15140-122). At confluency, cultures were rinsed with phosphate buffered saline (PBS) solution and harvested with Trypsin-EDTA (Invitrogen, 25200-072). Endothelial cells were stimulated with Tumor Necrosis Factor alpha (TNF-a) for 24 hrs $10 \mathrm{ng} / \mathrm{mL}$ (Chemicon, GF 023). 


\section{Model preparation}

The geometric model used is an idealized model of a coronary artery $(3.175 \mathrm{~mm}$ inner diameter, $10 \mathrm{~cm}$ length) presenting an eccentric stenosis with a 50\% area reduction $(16,17)$. Casts to create the lumen of the artery were made with a low melting point alloy (Cerrolow117 $7^{\mathrm{TM}}$, Cerro Metal Products). Transparent Sylgard184 ${ }^{\mathrm{TM}}$ (Dow Corning) silicone elastomer was poured around the lumen casts and allowed to cure. The casts were then removed from the models. This procedure was used previously to study endothelial cell morphology (18-20). The resulting model geometry is shown in Figure 1A. The models were hydrophilized using $75 \%$ sulphuric acid for 45 minutes, boiled in deionized water for 30 minutes and coated with $40 \mu \mathrm{g} / \mathrm{mL}$ fibronectin in deionized water (Sigma-Aldrich, F0895) overnight at $37^{\circ} \mathrm{C}$. Solutions were aspirated and the models washed with media once before the cells were seeded, at a seeding density of $1 \times 10^{6}$ cells $/ \mathrm{mL}\left( \pm 2 \times 10^{5}\right.$ cells $\left./ \mathrm{mL}\right)$ (Beckman Coulter).

\section{Perfusion flow loop}

The flow loop (Figure 1B) consisted of a reservoir, tubing, dampeners and an 8-rollers peristaltic pump head with a programmable drive (Ismatec, ISM 404 and ISM 732) producing a steady flowrate at the entrance of the models to match a mean entrance wall shear stress (WSS) of 1.25 and 6.25 dynes $/ \mathrm{cm}^{2}$. A water bath was used to heat the media in the reservoir which was supplemented with 25 mM HEPES (Invitrogen, 15630-080). The sterilized system was assembled and installed on an inverted microscope. In the section upstream of the model, a length of straight tubing was used to enable the flow to develop before entering the model. The viscosity $(0.78 \mathrm{cP})$ and density $\left(994.3 \mathrm{~kg} / \mathrm{m}^{3}\right)$ of the media were measured using a double gap rheometer (Bohlin, Model CVO $120 \mathrm{HR}$ ) and a pycnometer (Fisher Scientific, 3-247).

\section{Wall shear stress determination}

The photochromic dye tracer technique was used to verify the wall shear stress patterns within the models and to determine the points of separation and reattachment. In these experiments, an identical cast model to the cell culture model was perfused with a solution of odorless mineral spirits (Shell-Sol 715) and trace amounts of colourless dye $\left(1^{\prime}, 3^{\prime}, 3^{\prime}\right.$ trimethylindoline-6-nitro-benzospiropyran). When exposed to UV light from a laser, the solution turns opaque and forms a photochromic trace (21-24). A CCD camera (Dalsa Pantera TF IM60, Dalsa) and an image-processing board (National Instruments PCI 1428) were used to track the molecular displacement and calculate the wall shear rate. To account for differences in fluid properties, the mean entrance Reynolds number was matched ( $R e=165$ and $\mathrm{Re}=827$ ) corresponding to the 1.25 and 6.25 dynes $/ \mathrm{cm}^{2}$ mean entrance WSS of the cell culture experiments.

\section{Adhesion assay}

Adhesion assays were performed under static, low shear $\left(1.25 \mathrm{dyne} / \mathrm{cm}^{2}\right)$ and high shear (6.25 dynes $/ \mathrm{cm}^{2}$ ) conditions. The NB4 cells were circulated over either a TNF-a stimulated or a non-stimulated endothelium for 1 or $6 \mathrm{hrs}$. In a parallel set of experiments, the endothelial cells were pre-treated by shearing for $24 \mathrm{hrs}$ prior to the adhesion assay. The 
presheared models were washed twice with fresh media before the adhesion assay was performed. After washing, the models were inserted back in the flow loop and the pump was started, circulating fresh media.

In all experiments, the ATRA differentiated NB4 cells were resuspended in fresh media and the final concentration flowing over the endothelial cells was adjusted to $5 \times 10^{5}$ cells $/ \mathrm{mL}$ (Beckman Coulter) and injected in the media reservoir. After incubation, non-adherent cells were removed by flowing fresh media over the endothelial cells. The pump was stopped and the models were taken out of the loop. The models were washed with PBS twice and fixed for 20 minutes with $1 \%$ fresh paraformaldehyde (Sigma, P6148). The models were kept at $4^{\circ} \mathrm{C}$ in a solution (1:1) of PBS and glycerol (Sigma, G5516). For morphological observations and adhesion quantification, an inverted light microscope with a CCD camera was used (Leica, DMIL). Representative images $(n=3)$ of each region were taken and NB4 cells present in each field of view were counted in order to quantify cell adhesion. Videos were acquired using a high speed camera (Sony, DFW-X710) which allowed for the visualization of the tethering, rolling and attachment of the cells within each flow region.

\section{Analysis of cell surface adhesion molecules by confocal microscopy}

Fixed endothelial cells within the models were analyzed for ICAM-1 and VCAM-1 protein expression by immunofluorescence. Cells were washed with PBS, and blocked in $2 \%$ normal donkey serum (NDS, Jackson Immunoresearch, 017-000-121), 0.2\% Triton X-100 (Sigma, T8787) in PBS for 30 minutes at room temperature. Primary antibodies were diluted in $1 \%$ NDS, $0.05 \%$ Triton-X100 and incubated overnight at $4{ }^{\circ} \mathrm{C}$ in mouse monoclonal antiVCAM-1 (sc-20069,1:100, Santa Cruz Biotechnology) and anti-ICAM-1 (sc-8439, 1:100, Santa Cruz Biotechnology). After three PBS washes, secondary antibodies were incubated for $1 \mathrm{hr}$ at room temperature (Alexa Fluor 555 anti-mouse $\operatorname{IgG}$ (A31570), 1:600, Molecular Probes). TOPRO-3 nuclear counter stain was used for $1 \mathrm{hr}$ at room temperature (T3605, 1:300, Molecular Probes) after an RNAse treatment of 30 minutes (Sigma R6513, $1 \mathrm{mg}$ / $\mathrm{mL}$ ). Models were mounted using 0.2\% Dabco/Glycerol (Sigma D2522, 1:5). Cells were examined under a laser scanning confocal microscope (LSM 510, Zeiss), using HeNe1 (543 $\mathrm{nm})$ and $\mathrm{HeNe} 2(633 \mathrm{~nm})$ lasers for excitation of the fluorochromes and a 32x/0.4 A-Plan objective (Zeiss). Maximum intensity projections were produced from $\mathrm{Z}$ series using the LSM software (Zeiss).

\section{Analysis of protein expression using western blotting}

Control and stimulated straight/tubular models were assayed in parallel to quantify protein expression after TNF-a stimulation by western blot. Cells were collected from the models and lysed in RIPA lysis buffer (50 mM Tris- $\mathrm{HCl}$ (pH 6.8), $150 \mathrm{mM} \mathrm{NaCl}, 1 \% \mathrm{NP}-40,0.5 \%$ Sodium Deoxycholate, $0.1 \%$ SDS) with protease inhibitor cocktail (Sigma, P8340). The cells were lysed using three cycles of freezing and thawing, with vortexing and a final sonication step of 30 minutes on ice. Cell debris were separated from proteins by centrifugation at $16,000 \mathrm{~g}$ for 15 minutes at $4^{\circ} \mathrm{C}$. After quantification using the bicinchoninic acid assay (Pierce), proteins were resuspended in $12 \mathrm{mM}$ Tris-HCl, 10\% glycerol, $0.4 \%$ SDS and $0.02 \%$ bromophenol blue and boiled for 5 minutes. The proteins $(2 \mu \mathrm{g})$ were then loaded on 7\% polyacrylamide gels (30\% w/v, 1:29.2) and run in a Mini Protean III apparatus 
(Biorad). The proteins were transferred on polyvinylidene fluoride (PVDF) membranes in a Transblot apparatus (Biorad). The membranes were incubated for 30 minutes at room temperature in $5 \%$ nonfat dry milk in $0.1 \%$ Tween-20 in PBS to block nonspecific protein binding and incubated overnight in primary antibody in $0.05 \%$ Tween-20, $2 \%$ Milk in PBS. Antibodies for ICAM-1 (sc-8439, 1:100, Santa Cruz Biotechnology), $\beta$-actin (sc-47778, 1:200, Santa Cruz Biotechnology) and VCAM-1 (sc-8304, 1:100, Santa Cruz Biotechnology) were used. After washing in a solution of PBS and Tween-20, secondary antibodies were incubated for $1.5 \mathrm{hrs}$ at room temperature (goat anti-rabbit and anti-mouse IgG, 1:10,000, Biorad). The membranes were washed and signal detected using enhanced chemiluminescence method (Pierce) and X-Ray films (X-Omat, Kodak) were exposed.

\section{Statistical analysis}

Results are expressed as mean \pm standard deviation. All experiments were performed at least in triplicates. Graphpad Prism 5 (Graphpad Software, La Jolla, CA) was used to analyze the results. Comparisons were made with One-way and Two-way ANOVAs when appropriate followed by multiple comparisons test (Bonferroni post-tests). Differences between means were considered significant at $\mathrm{P}<0.05$.

\section{Results}

\section{Asymmetric stenosis model and hemodynamic regions}

The asymmetric geometry of the $50 \%$ stenosis creates a complex flow field distal to the stenosis at a Reynolds number of 165 and 827 , Figure $1 \mathrm{C}(\mathrm{Re}=165)$. The wall shear stress patterns and location of the separation and reattachment points, defining the recirculation region, were measured using the photochromic dye tracer method. At the entrance of the model, flow was steady and had a parabolic velocity profile. Wall shear stress increases along the stenosis wall as the model constricts and reaches a peak of approximately 3.5 times the inlet wall shear stress just upstream of the stenosis peak. The near wall fluid velocity slows downstream of the stenosis and separates $2.5 \mathrm{~mm}$ downstream of the peak. A recirculation zone is created in this region of adverse pressure gradient which extends to the reattachment point approximately $7.5 \mathrm{~mm}$ downstream of the stenosis peak. With increasing Reynolds number, the separation point remained more or less at the same location, however, the reattachment point moved further downstream. The values of wall shear stress magnitude and gradients are presented in Figure 1D and 1E.

\section{Endothelial cell expression of ICAM-1 and VCAM-1: effect of stimulation and shear magnitude}

Endothelial cell response to stimulation and shear was analyzed in terms of ICAM-1 and VCAM-1 expression in the inlet region of the models. Stimulation of endothelial cells with TNF-a for 24 hrs upregulated ICAM-1 and VCAM-1 expression, Figure 2A. The total protein levels of ICAM-1 and VCAM-1 were determined by western blotting and were visibly upregulated with stimulation time, Figure 2B.

Upregulation of ICAM-1 and VCAM-1 using TNF- $a$ was time and shear dependent. The effect of TNF-a on CAM expression was noticeably reduced by $1 \mathrm{hr}$ under static conditions, 
Figure 3. Flow prolonged and/or increased the expression of ICAM-1 and VCAM-1. At low shear (1.25 dyne $\left./ \mathrm{cm}^{2}\right)$ the expression of ICAM-1 and VCAM-1 was visually increased after $1 \mathrm{hr}$ when compared to the static controls, Figure 3. At high shear $\left(6.25 \mathrm{dynes} / \mathrm{cm}^{2}\right)$ cell adhesion molecules were expressed at a lower level than at the lower shear, however still increased in comparison to the static controls. EC not exposed to TNF-a had very low basal expression of ICAM-1 and VCAM-1 and no noticeable differences were evident with time or shear.

\section{Neutrophil adhesion: effect of shear magnitude and assay duration}

Stimulation of NB4 cells with ATRA increased their adhesion to ECs significantly, Figure 4A, and all subsequent adhesion experiments were performed with ATRA stimulated NB4 cells. NB4 cells tended to preferentially adhere at the endothelial cell-endothelial cell junctions instead of at the nuclear area. This was observed both statically (Figure 4B) and under flow (Figure 4C). It was also observed on video that cells appeared to adhere in a more rapid and firm manner in the regions of lower wall shear stress (data not shown).

The adhesion of NB4 cells to endothelial cells in the one dimensional flow regions of the models (inlet and distal) was assessed to distinguish the influence of wall shear stress magnitude, TNF-a stimulation and assay duration. Static adhesion tests were performed along with different wall shear stress values. Representative images of the adhesion of NB4 cells on ECs are shown in Figure 5A-C. Adhesion data is presented for the cells in the steady unidirectional flow regions at the entrance and exit of the model in Figure 5D-H. As seen, TNF- $\alpha$ stimulation and assay duration significantly increased adhesion $(\mathrm{P}<0.0001$ and $\mathrm{P}<0.0001$, Two-way ANOVA), whereas, wall shear stress decreased it.

Under static conditions, significantly more NB4 cells adhered on TNF-a stimulated cells at 1 and 6 hrs when compared to control endothelial cells, Figure 5D ( $\mathrm{P}<0.001$, Bonferroni post-test). There was no difference in adhesion between the 1 and $6 \mathrm{hrs}$ static experiments for the non-stimulated ECs. Flow reduced the overall adhesion to the TNF-a stimulated and non-stimulated endothelial cells, Figure 5D-F. . Overall, low shear $\left(1.25 \mathrm{dyne} / \mathrm{cm}^{2}\right)$ reduced the adhesion by about 3 fold and high shear $\left(6.25\right.$ dynes $\left./ \mathrm{cm}^{2}\right)$ by 15 fold when compared to the static control models. Both time and the level of shear effected cell adhesion under flow $(\mathrm{P}<0.0001, \mathrm{P}<0.0001$, Two-way ANOVA), Figure 5G-H. More cells adhered with increased perfusion time at low and high shear, with the most noticeable difference seen in the nonstimulated cells. At higher shear $\left(6.25\right.$ dynes $\left./ \mathrm{cm}^{2}\right)$, there was no difference between the stimulated and non-stimulated cells by $6 \mathrm{hrs,} \mathrm{however,} \mathrm{in} \mathrm{all} \mathrm{other} \mathrm{conditions,} \mathrm{stimulation}$ had a significant impact on cell adhesion $(\mathrm{P}<0.0001$, Bonferroni post-tests). At even higher shear values (12.5 dynes $/ \mathrm{cm}^{2}$, data not shown) very few cells adhered to either the stimulated or non-stimulated endothelial cells, limiting statistical analysis.

\section{Regional endothelial cell expression of ICAM-1 and VCAM-1}

Regionally, there appeared to be higher levels of VCAM-1 near the stenosis peak for the 1.25 dyne $/ \mathrm{cm}^{2}$ models, Figure 6. ICAM-1 expression changes were less apparent. At 6.25 dynes $/ \mathrm{cm}^{2}$, there was less VCAM-1 and ICAM-1 signal and no noticeable difference in 
expression was observed (data not shown). The bright circular spots, present mainly in the recirculation and distal regions, are adhered NB4 cells.

\section{Regional adhesion of neutrophils}

Adhesion in the models was quantified systematically in the regions presented in Figure 1.

Videos of the adhesion assay clearly showed the region of flow recirculation downstream of the stenosis (data not shown). A distinct line of attachment was seen near the separation point distal to the stenosis and the recirculation point showed neutrophils oscillating and being split on either sides.

When quantifying the regional attachment an average over the region was used. Figure 7 shows the regional adhesion variation in the perfused models. There appears to be a distinct regional pattern of attachment. In general, the recirculation zone had the most attached NB4 cells. Activation of endothelial cells with TNF- $a$ increased significantly the overall attachment everywhere except at the peak of the stenosis, most probably due to the high shear present in this region. The adhesion was not only dependent on the location but also on time and shear magnitude for all cases (Two-way ANOVA). Without stimulation, no noticeable regional differences occur until after 6 hrs of adhesion. At low shear (1.25 dyne $/ \mathrm{cm}^{2}$ ) attachment to the non-stimulated EC was significantly greater in the recirculation and distal regions by $6 \mathrm{hrs}$. Stimulating the cells increased the attachment at all locations with the exception of the peak of the stenosis. With a stimulated EC layer at low shear, both time and location had a significant effect on adhesion $(\mathrm{P}<0.0001$ for both time and location, Two-way ANOVA). The peak and recirculation regions showed the most difference with few cells attaching to the peak and the most cells attaching in the recirculation region, Figure 7. The same pattern of adhesion is seen at 1 and $6 \mathrm{hrs}$, however, time appears to amplify this pattern. At $1 \mathrm{hr}$, the recirculation region has significantly more cells than all other locations (Bonferroni post-tests). By $6 \mathrm{hrs}$, the accumulation in the proximal and distal regions is similar to the recirculation region, and these two regions had more cells than the inlet $(\mathrm{P}<0.01$ for both, Bonferroni post-tests). There were significantly fewer cells at the peak than at all other regions at $6 \mathrm{hrs}$. At the higher shear $\left(6.25 \mathrm{dynes} / \mathrm{cm}^{2}\right)$, there were significantly less cells attached. Only the peak region could be easily distinguished as different. For both the stimulated and non-stimulated endothelium, there was significantly less attachment in the peak region than all other regions.

\section{Effect of endothelial cell preshearing}

Preshearing the ECs for 24 hrs prior to the adhesion assay was conducted to evaluate the adaptive effect of shear on the ECs. It lowered their cell adhesion molecule expression, as shown in Figure 8. This was clearly visible in the TNF-a stimulated cells. Preshearing seemed to have a greater effect on ICAM-1 than VCAM-1.

Adhesion experiments lasting $1 \mathrm{hr}$ were conducted at low shear $\left(1.25 \mathrm{dyne} / \mathrm{cm}^{2}\right)$ following preshearing $\left(1.25\right.$ dyne $\left./ \mathrm{cm}^{2}\right)$ for $24 \mathrm{hrs}$. Preshearing significantly decreased the adhesion of NB4 cells to non stimulated and TNF-a stimulated endothelial cells in the one dimensional flow regions $(\mathrm{P}=0.007$ and $\mathrm{P}<0.0001$ respectively, Two-way ANOVA), Figure $9 \mathrm{~A}$. This effect was seen in all regions, Figure 9B. Shearing had less effect on adhesion on the non- 
stimulated endothelial cells. At the inlet, a decrease in adhesion of approximately 2.5 fold is noticed in the presheared models. To better separate the global and local response of the ECs to preshearing, the fold increase with respect to the inlet was calculated (Figure 9C). With the quiescent endothelial cells prior to adhesion assay, the recirculation region showed a 2-3 fold increase in cell attachment. Preshearing the cells significantly increased the normalized attachment in the recirculation zone to $6-8$ fold in both the stimulated and non-stimulated models ( $\mathrm{P}<0.001$ and $\mathrm{P}<0.05$, Bonferroni post-tests respectively). This suggests a differential response in the regional adhesion in the recirculation zone due to the preshearing of the cells, suggesting a local change in phenotype.

Regionally expression of ICAM-1 and VCAM-1 was assessed through confocal microscopy. Presheared cells appeared to express higher levels of ICAM-1 and VCAM-1 in the recirculation region for the $1.25 \mathrm{dyne} / \mathrm{cm}^{2}$ models than in other regions, Figure 10. In all regions, the expression of ICAM-1 and VCAM-1 appear lower than in cells that were not presheared, comparing Figure 6 and 10 levels, acquired with the same parameters.

\section{Discussion}

Inflammation and adhesion of leukocytes to the endothelium is a critical step in the initiation and progression of atherosclerosis. In vivo post-mortem studies have revealed that plaque disruption usually occurs at the shoulders $(6,25-27)$, where the cap is often thinnest and most heavily infiltrated with white blood cells including neutrophils and monocytes (28). Inflammatory markers are also differentially expressed in vivo in disturbed flow regions, such as those created by an eccentric stenosis $(29,30)$. It is believed that local hemodynamic factors and mass transport dictate plaque stability and rupture location. In this study, we show for the first time that the flow patterns created by a 50\% area stenosis can locally increase the attachment of a neutrophil-like cell line when compared to uniform flow regions. The overall number of cells adhered depended on the phenotype of the endothelial cells, the magnitude of entrance shear stress and the duration of the adhesion assay. Taken together, this work may help to explain the presence and location of leukocytes in unstable plaques.

Most of our understanding of leukocyte adhesion and endothelial cell dysfunction has come from parallel plate and rotational viscometer cell culture experiments $(31,32)$. These studies have demonstrated that leukocyte attachment is dependent on the magnitude of the hydrodynamic forces, the contact frequency and duration, and the cellular response to shear stress $(29,33-36)$. These studies have mainly been limited to exposure with steady flow and hence constant shear stresses. Few studies have incorporated more complex flow fields $(29,37)$ and none have investigated the attachment around an idealized stenosis, Figure 1.

In this study, both a non-stimulated and an inflamed (TNF-a stimulated) endothelium were used. TNF-a stimulation upregulates the expression of cell adhesion molecules (Figure 2), which are expressed in atheroprone regions and regions presenting plaque $(30,38)$. It thus creates a dysfunctional endothelium, characterized by the expression of pro-inflammatory molecules and other ligands supporting leukocyte adhesion (39). Adhesion molecules, specifically intracellular adhesion molecule-1 (ICAM-1) and vascular adhesion molecule-1 
(VCAM-1), bind integrins expressed on leukocytes and direct their adhesion, eventually leading to transmigration across the endothelium (40-42). The expression of ICAM-1 and VCAM-1 was upregulated in HAECs treated with TNF- $a$, as detected by confocal microscopy and western blotting, thus behaving similarly to other endothelial cell lines, Figure 2. ATRA-induced NB4 cells, by the transition from the promyelocyte to the neutrophilic myelocyte stage, have been proven to show a number of markers of the granulocytic lineage and increased expression of a 4 (VLA4) and $\beta 2$ (LFA-1, Mac-1), therefore, increasing adhesion to the endothelium statically (42-45). Neutrophils have been identified at sites of plaque rupture, infiltrating in culprit lesions in acute coronary syndromes and have been found to accumulate at sites of denudation, despite being the first appearing phagocytes cells in acute inflammatory responses to tissue injury (46). In this study, we show the complexity of the adhesion of neutrophil-like cells in a stenotic region, which was not previously appreciated.

As previously observed (47), the attachment of NB4 cells occurred at the junction between endothelial cells, Figure 3. Removal of TNF-a stimulation caused a decrease in the expression of cell adhesion molecules, Figure 4, however, under low shear, higher expression was observed. Increasing adhesion time significantly influenced the total adhesion at both shear magnitudes. This effect was most evident in the non-stimulated cells where overall fewer cells adhered, Figure 5. Under flow, adhesion is significantly influenced by wall shear stress magnitude, with increased wall shear stress resulting in an overall reduction in adhesion. The magnitude of wall shear stress determines many parameters that affect leukocyte adhesion, most directly the hydrodynamic forces that drive cell motion (32). In our experiments, there seems to be a limit to the attachment to non-stimulated endothelial cells under static adhesion, as a maximum was reached after $1 \mathrm{hr}$. This might be explained by a limited number of ligands available or a limitation of the neutrophil density in suspension. Under flow, the overall attachment values were similar to the static values at 6 hrs for both low $\left(1.25 \mathrm{dyne} / \mathrm{cm}^{2}\right)$ and high $\left(6.25 \mathrm{dynes} / \mathrm{cm}^{2}\right)$ shear experiments. The TNF-a stimulated endothelial cells showed increased NB4 adhesion at 6 hrs and adhesion under flow was significantly less at both shear levels, never reaching levels of static adhesion.

Very few studies have looked at the regional attachment of leukocytes in regions of complex flow dynamics. In an idealized model of a bifurcation, Cicha et al. found more THP-1 monocytes adhered to HUVECs in the region of non-uniform shear stress created by the expansion at the bifurcation $(37,48)$. Burns and DePaola used a reverse step to evaluate the attachment of U-937 cells to HUVECs. Under their flow conditions, attachment was only found in the recirculation zone and none was seen in the recovery region distal to the reattachment point (29). In the same reverse step model, Chen et al. showed that neutrophils, lymphocytes and monocytes adhered and transmigrated more in the reattachment region than in the recirculation and did not note any real difference between the recirculation and recovery (distal) regional attachment (13). They hypothesize a longer residence time and a higher near wall concentration as cells roll more slowly in the reattachment point compared to other areas possibly causing this preferential attachment. In an axisymmetric stenosis model, Hinds et al. found the attachment of U-937 cells to an E-selectin layer to be negatively correlated with the magnitude of wall shear stress in the constricted region (proximal) and stenosis region (49). It must be noted that this was a highly idealized stenosis 
model consisting of a linear constriction and reverse step, and the shear stress applied was an order of magnitude less than in our experiments. Interestingly, the greatest attachment was seen in the proximal portion of their model in the region of positive shear stress gradient and elevated shear stress.

When comparing these previous finding to ours, it must be noted that there are significant differences in the magnitude, duration and cell lines used. In addition, our model does not have any sharp corners and therefore presents more realistic local hemodynamics. Under the flow conditions evaluated, $(\mathrm{Re}=167$ and 827$)$ a stable recirculation zone appears downstream of the stenosis. At low shear stress $\left(1.25 \mathrm{dyne} / \mathrm{cm}^{2}\right)$ at $1 \mathrm{hr}$, the recirculation zone contained the most adherent NB4 cells in the presence of a TNF- $a$ stimulated endothelium, Figure 7. Unlike Chen et al. we did not find leukocyte clustering at the reattachment point (13). This may be due to a well documented instability of the reattachment point, creating high temporal shear stress gradients (50). We did note a distinct line of attachment at the separation point (data not shown). This very focal adhesion could be due to the minimum shear stress and lack of momentum of the cells as they flow in reverse along the recirculation region to this point.

At peak stenosis, where the shear stress is highest, we saw significantly less attachment in the TNF- $a$ stimulated cells for all conditions and in the non-stimulated cells at high shear stress and longer time. This is likely explained by the dominance of hydrodynamic forces at this location. Furthermore, at higher shear, this force was enough to strip some of the endothelial cells. With the exception of the $1 \mathrm{hr}$ time point at low shear on the TNF-a stimulated endothelium, the attachment in the recovery or distal region was similar to the recirculation zone, Figure 7. The probability of adhesion may be increased in this region owing to the increased contact time and the potential cell activation due to cells interactions (32). Chen et al. also found little difference between the recirculation and recovery regions at higher wall shear stresses in a reverse step model. Finally, it is interesting to note that although not significant, there was a tendency for more cells to adhere in the proximal region than the inlet. This is an area of increased shear stress as the geometry creates a positive shear gradient. Hinds et al. found a similar increased adhesion of U-937 cells to the proximal part of the constriction in their idealized E-selectin coated axisymmetric stenosis (49). Taken together, our results and previous studies suggest that there is more firm attachment of leukocytes to an endothelium in the presence of complex shear gradients (31$33)$.

To investigate the role of local adaptation of endothelial cells to flow, we also conducted preshearing prior to some of the adhesion assays. Preshearing the endothelial cells decreased their expression of CAMs in the one dimensional flow regions (Figure 8); this may explain the drastic drop in adhesion throughout the models. Sheikh et al. found preshearing to reduce the response of ECs to TNF- $a$ and the subsequent adhesion (51). Ando et al. also found preshearing to decrease adhesion (52).

Although preshearing decreased the overall and localized cell adhesion, preshearing also appeared to have a localized effect. In both the TNF- $a$ stimulated and non-stimulated cells, preshearing noticeably increased the adhesion difference between the inlet and recirculation 
regions, Figure 9. Local differences in cell adhesion molecule expression between the presheared and quiescent models were observed through confocal microscopy, (Figure 10). The sensitivity of the confocal analysis was limited and qualitative. However, an interesting greater difference between the inlet and the recirculation regions was noted in presheared when compared to quiescent cells. This suggests that preshearing has a differential effect in the unidirectional flow regions compared to the region of flow reversal distal to the stenosis. In this sense, traditional models are adequate to detect homogeneous changes and response of endothelium to shear forces, but cannot be used to reveal the more subtle heterogeneous response caused by adaptation of the endothelial cells to local hemodynamics.

Many assumptions were made in this study to make it feasible. In vitro dynamic cell culture models were used to simulate in vivo response. The wall shear stress values used are in the low physiological range but within the range for leukocyte adhesion assays. Although limiting assumptions were made, this work is a significant improvement from previous studies as it subjects endothelial cells and blood components to realistic hemodynamic gradients in a controlled environment. As with any experimental model, the pathophysiological plausibility of the findings can only be established when carefully analyzed in the context of other experimental and clinical data.

Facilitating inflammation is a hallmark of endothelial cell dysfunction. Inflammatory processes are important in all stages of atherosclerosis development including the initiation, progression and plaque disruption (53). The asymmetric stenosis model presented creates a complex hemodynamic environment. In established plaques in vivo, inflammatory cell recruitment produces various enzymes and pro-coagulation factors (54). Enzymatic activity is believed to destabilize the fibrous cap and lead to plaque rupture. A more realistic model like this one, can improve our understanding of the possible location for plaque rupture and the progression once a plaque has formed, with one of the first step being leukocyte adhesion. The videos acquired provided clues on the possible reasons of the increased adhesion in the recirculation zone distal to the stenosis. Adhesion was higher in wall shear stress gradient regions, both proximal and distal to the stenosis. Neutrophils were entrapped in the recirculation zone, with resulting enhanced contact time and possible activation with endothelial cell contact. This is of great clinical interest as it is believed that plaque rupture occurs preferentially at the shoulders of the plaque.

\section{Acknowledgments}

We thank L. Danielczak and K. Markey for their technical assistance in the experiments.

This work was supported by grants from the Canadian Foundation for Innovation (CFI), the National Sciences and Engineering Research Council (NSERC), the Canadian Institutes of Health Research (CIHR), the Fonds Québécois de la Recherche sur la Nature et les Technologies (FQRNT) and the Eugenie Ulmer Lamothe Fund (EUL).

\section{References}

1. Libby P. Inflammation in atherosclerosis. Nature. 2002; 420(6917):868-874. [PubMed: 12490960]

2. Virmani R, Allen PBU. Pathology of the Thin-Cap Fibroatheroma. Journal of Interventional Cardiology. 2003; 16(3):267-272. [PubMed: 12800406] 
3. Walpola PL, Gotlieb AI, Cybulsky MI, Langille BL. Expression of ICAM-1 and VCAM-1 and monocyte adherence in arteries exposed to altered shear stress. Arterioscler Thromb Vasc Biol. 1995; 15(1):2-10. [PubMed: 7538423]

4. Libby P, Theroux P. Pathophysiology of Coronary Artery Disease. Circulation. 2005; 111(25):34813488. [PubMed: 15983262]

5. Stary HC, Chandler AB, Dinsmore RE, Fuster V, Glagov S, Insull W Jr, Rosenfeld ME, Schwartz CJ, Wagner WD, Wissler RW. A Definition of Advanced Types of Atherosclerotic Lesions and a Histological Classification of Atherosclerosis: A Report From the Committee on Vascular Lesions of the Council on Arteriosclerosis, American Heart Association. Circulation. 1995; 92(5):13551374. [PubMed: 7648691]

6. Richardson PD, Davies MJ, Born GVR. Influence of plaque configuration and stress distribution on fissuring of coronary atherosclerotic plaques. The Lancet. 1989; 334(8669):941-944.

7. Kovanen PT. Mast cells and degradation of pericellular and extracellular matrices: potential contributions to erosion, rupture and intraplaque haemorrhage of atherosclerotic plaques. Biochem Soc Trans. 2007; 035(5):857-861.

8. Ku DN, Giddens DP, Zarins CK, Glagov S. Pulsatile flow and arherosclerosis in human carotid bifurcation: Positive correlation between plaque location and low and oscillating shear stress. Arteriosclerosis. 1985; 5:293-302. [PubMed: 3994585]

9. DeBakey ME, Lawrie GM, Glaeser DH. Patterns of atherosclerosis and their surgical significance. Ann Surg. 1985; 201(2):115-131. [PubMed: 3155934]

10. Nerem RM, Alexander RW, Chappell DC, Medford RM, Varner SE, Taylor WR. The study of the influence of flow on vascular endothelial biology. Am J Med Sci. 1998; 316(3):169-175. [PubMed: 9749558]

11. Gimbrone MA Jr, Nagel T, Topper JN. Biomechanical activation: an emerging paradigm in endothelial adhesion biology. J Clin Invest. 1997; 100(11 Suppl):S61-S65. [PubMed: 9413404]

12. Tsou JK, Gower RM, Ting HJ, Schaff UY, Insana MF, Passerini AG, Simon SI. Spatial regulation of inflammation by human aortic endothelial cells in a linear gradient of shear stress. Microcirculation. 2008; 15(4):311-323. [PubMed: 18464160]

13. Chen CN, Chang SF, Lee PL, Chang K, Chen LJ, Usami S, Chien S, Chiu JJ. Neutrophils, lymphocytes, and monocytes exhibit diverse behaviors in transendothelial and subendothelial migrations under coculture with smooth muscle cells in disturbed flow. Blood. 2006; 107(5):19331942. [PubMed: 16293605]

14. Montoya MC, Luscinskas FW, del Pozo MA, Aragones J, de Landazuri MO. Reduced intracellular oxidative metabolism promotes firm adhesion of human polymorphonuclear leukocytes to vascular endothelium under flow conditions. Eur J Immunol. 1997; 27(8):1942-1951. [PubMed: 9295030]

15. Rainger GE, Fisher AC, Nash GB. Endothelial-borne platelet-activating factor and interleukin-8 rapidly immobilize rolling neutrophils. Am J Physiol. 1997; 272(1 Pt 2):H114-H122. [PubMed: 9038929]

16. Brunette J, Mongrain R, Cloutier G, Bertrand M, Bertrand OF, Tardif JC. A novel realistic threelayer phantom for intravascular ultrasound imaging. Int J Cardiovasc Imaging. 2001; 17(5):371381. [PubMed: 12025951]

17. Brunette J, Mongrain R, Laurier J, Galaz R, Tardif JC. 3D flow study in a mildly stenotic coronary artery phantom using a whole volume PIV method. Med Eng Phys. 2008; 30(9):1193-1200. [PubMed: 18406195]

18. Farcas M, Rouleau L, Fraser R, Leask R. The development of 3-D, in vitro, endothelial culture models for the study of coronary artery disease. Biomed Eng Online. 2009; 8(1):30. [PubMed: 19863806]

19. Rouleau L, Farcas M, Copland I, Tardif JC, Mongrain R, Leask RL. Morphological and functional flow-induced response of endothelial cells and adhesive properties of leukocytes in 3D stenotic models. IFMBE Proceedings. 2009; 22(15):2015-2018.

20. Rouleau L, Farcas M, Tardif JC, Thorin E, Mongrain R, Leask RL. Endothelial cell morphology and response to shear stress in an asymmetric stenosis model. J Biomech. 2006; 39(S1):S312.

21. Ojha M, Cobbold RS, Johnston KW. Influence of angle on wall shear stress distribution for an endto-side anastomosis. J Vasc Surg. 1994; 19(6):1067-1073. [PubMed: 8201708] 
22. Ojha M, Cobbold RSC, Johnston KW, Hummel RL. Pulsatile flow through constricted tubes: an experimental investigation using photochromic tracer methods. J Fluid Mech. 1989; 203(1):173197.

23. Couch GG, Johnston KW, Ojha M. Full-field flow visualization and velocity measurement with a photochromic grid method. Meas Sci Technol. 1996; 7:1238-1246.

24. Leask RL, Wayne JK, Ojha M. Hemodynamic Effects of Clot Entrapment in the TrapEase Inferior Vena Cava Filter. J Vasc Interv Radiol. 2004; 15(5):485-490. [PubMed: 15126659]

25. Falk E, Shah PK, Fuster V. Coronary plaque disruption. Circulation. 1995; 92(3):657-671. [PubMed: 7634481]

26. Dirksen MT, van der Wal AC, van den Berg FM, van der Loos CM, Becker AE. Distribution of inflammatory cells in atherosclerotic plaques relates to the direction of flow. Circulation. 1998; 98(19):2000-2003. [PubMed: 9808596]

27. Viles-Gonzalez JF, Fuster V, Badimon JJ. Atherothrombosis: a widespread disease with unpredictable and life-threatening consequences. Eur Heart J. 2004; 25(14):1197-1207. [PubMed: 15246637]

28. Libby P, Ridker PM, Maseri A. Inflammation and Atherosclerosis. Circulation. 2002; 105(9):11351143. [PubMed: 11877368]

29. Burns MP, DePaola N. Flow-conditioned HUVECs support clustered leukocyte adhesion by coexpressing ICAM-1 and E-selectin. Am J Physiol Heart Circ Physiol. 2005; 288(1):H194-H204. [PubMed: 15331359]

30. Dai G, Kaazempur-Mofrad MR, Natarajan S, Zhang Y, Vaughn S, Blackman BR, Kamm RD, Garcia-Cardena G, Gimbrone MA Jr. Distinct endothelial phenotypes evoked by arterial waveforms derived from atherosclerosis-susceptible and -resistant regions of human vasculature. Proc Natl Acad Sci U S A. 2004; 101(41):14871-14876. [PubMed: 15466704]

31. Gimbrone MA Jr, Topper JN, Nagel T, Anderson KR, Garcia-Cardena G. Endothelial dysfunction, hemodynamic forces, and atherogenesis. Ann N Y Acad Sci. 2000; 902:230-239. [PubMed: 10865843]

32. Simon SI, Goldsmith HL. Leukocyte adhesion dynamics in shear flow. Ann Biomed Eng. 2002; 30(3):315-332. [PubMed: 12051617]

33. Finger EB, Puri KD, Alon R, Lawrence MB, von Andrian UH, Springer TA. Adhesion through Lselectin requires a threshold hydrodynamic shear. Nature. 1996; 379(6562):266-269. [PubMed: 8538793]

34. Theilmeier G, Lenaerts T, Remacle C, Collen D, Vermylen J, Hoylaerts MF. Circulating activated platelets assist THP-1 monocytoid/endothelial cell interaction under shear stress. Blood. 1999; 94(8):2725-2734. [PubMed: 10515876]

35. Chung TW, Tyan YC, Hsieh JH, Wang SS, Chu SH. Shear stress-induced aggregation of oxidized platelets. Thromb Res. 2002; 105(4):325-329. [PubMed: 12031827]

36. Feng S, Lu X, Resendiz JC, Kroll MH. Pathological shear stress directly regulates platelet alphaIIbbeta3 signaling. Am J Physiol Cell Physiol. 2006; 291(6):C1346-C1354. [PubMed: 16822941]

37. Cicha I, Goppelt-Struebe M, Yilmaz A, Daniel WG, Garlichs CD. Endothelial dysfunction and monocyte recruitment in cells exposed to nonuniform shear stress. Clin Hemorheol Microcirc. 2008; 39(1-4):113-119. [PubMed: 18503117]

38. Garcia-Cardena G, Comander J, Anderson KR, Blackman BR, Gimbrone MA Jr. Biomechanical activation of vascular endothelium as a determinant of its functional phenotype. Proc Natl Acad Sci U S A. 2001; 98(8):4478-4485. [PubMed: 11296290]

39. Chen CC, Manning AM. Transcriptional regulation of endothelial cell adhesion molecules: a dominant role for NF-kappa B. Agents Actions Suppl. 1995; 47:135-141. [PubMed: 7540353]

40. Price DT, Loscalzo J. Cellular adhesion molecules and atherogenesis. Am J Med. 1999; 107(1):8597. [PubMed: 10403357]

41. Marchetti AF. All-trans-retinoic acid increases adhesion to endothelium of the human promyelocytic leukaemia cell line NB4. British Journal of Haematology. 1996; 93(2):360-366. [PubMed: 8639429] 
42. Falanga A, Marchetti M, Giovanelli S, Barbui T. All-trans-retinoic acid counteracts endothelial cell procoagulant activity induced by a human promyelocytic leukemia-derived cell line (NB4). Blood. 1996; 87(2):613-617. [PubMed: 8555483]

43. Marchetti M, Falanga A, Giovanelli S, Oldani E, Barbui T. All-trans-retinoic acid increases adhesion to endothelium of the human promyelocytic leukaemia cell line NB4. Br J Haematol. 1996; 93(2):360-366. [PubMed: 8639429]

44. Khanna-Gupta A, Kolibaba K, Zibello TA, Berliner N. NB4 cells show bilineage potential and an aberrant pattern of neutrophil secondary granule protein gene expression. Blood. 1994; 84(1):294302. [PubMed: 7517212]

45. Koller A, Sun D, Kaley G. Role of shear stress and endothelial prostaglandins in flow- and viscosity-induced dilation of arterioles in vitro. Circ Res. 1993; 72(6):1276-1284. [PubMed: 8495555]

46. Lindstedt KA, Leskinen MJ, Kovanen PT. Proteolysis of the Pericellular Matrix: A Novel Element Determining Cell Survival and Death in the Pathogenesis of Plaque Erosion and Rupture. Arterioscler Thromb Vasc Biol. 2004; 24(8):1350-1358. [PubMed: 15191939]

47. Gopalan PK, Burns AR, Simon SI, Sparks S, McIntire LV, Smith CW. Preferential sites for stationary adhesion of neutrophils to cytokine-stimulated HUVEC under flow conditions. J Leukoc Biol. 2000; 68(1):47-57. [PubMed: 10914489]

48. Cicha I, Beronov K, Lopez Ramirez E, Osterode K, Goppelt M, Raaz D, Yilmaz A, Daniel WG, Garlichs CD. Shear stress preconditioning modulates endothelial susceptibility to circulating TNF$\hat{\mathrm{I}} \pm$ and monocytic cell recruitment in a simplified model of arterial bifurcations. Atherosclerosis. 2009

49. Hinds MT, Park YJ, Jones SA, Giddens DP, Alevriadou BR. Local hemodynamics affect monocytic cell adhesion to a three-dimensional flow model coated with E-selectin. J Biomech. 2001; 34(1):95-103. [PubMed: 11425085]

50. Ojha M, Cobbold RS, Johnston KW, Hummel RL. Detailed visualization of pulsatile flow fields produced by modelled arterial stenoses. J Biomed Eng. 1990; 12(6):463-469. [PubMed: 2266741]

51. Sheikh S, Rahman M, Gale Z, Luu NT, Stone PC, Matharu NM, Rainger GE, Nash GB. Differing mechanisms of leukocyte recruitment and sensitivity to conditioning by shear stress for endothelial cells treated with tumour necrosis factor-alpha or interleukin-1beta. Br J Pharmacol. 2005; 145(8): 1052-1061. [PubMed: 15912126]

52. Ando J, Nomura H, Kamiya A. The effect of fluid shear stress on the migration and proliferation of cultured endothelial cells. Microvasc Res. 1987; 33(1):62-70. [PubMed: 3561268]

53. Burke AP, Kolodgie FD, Farb A, Weber D, Virmani R. Morphological predictors of arterial remodeling in coronary atherosclerosis. Circ. 2002; 105(3):297-303.

54. Stary HC, Chandler AB, Dinsmore RE, Fuster V, Glagov S, Insull W Jr, Rosenfeld ME, Schwartz CJ, Wagner WD, Wissler RW. A Definition of Advanced Types of Atherosclerotic Lesions and a Histological Classification of Atherosclerosis: A Report From the Committee on Vascular Lesions of the Council on Arteriosclerosis, American Heart Association. Circulation. 1995; 92(5):13551374. [PubMed: 7648691] 
A

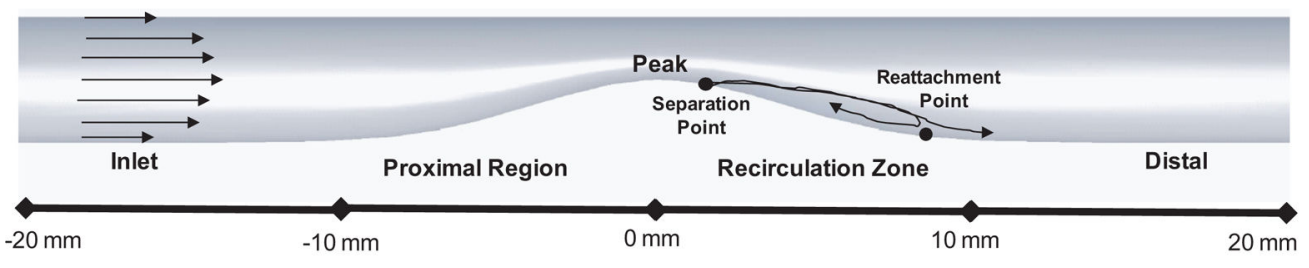

B

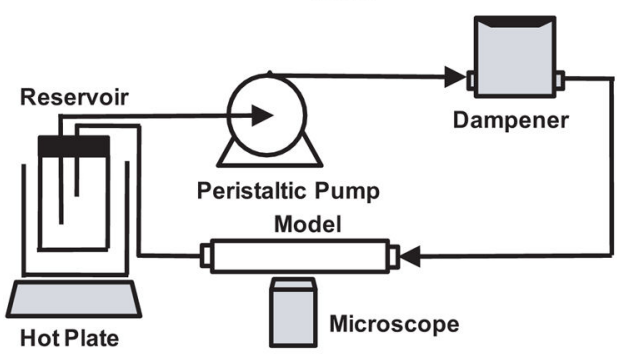

C

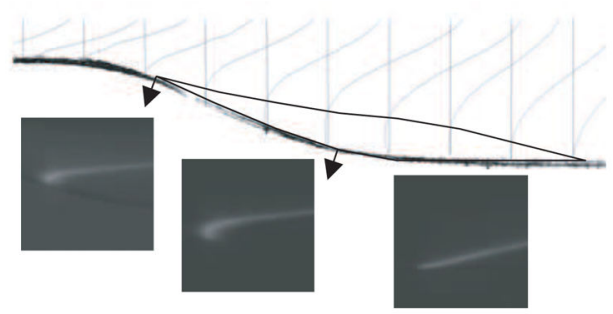

D

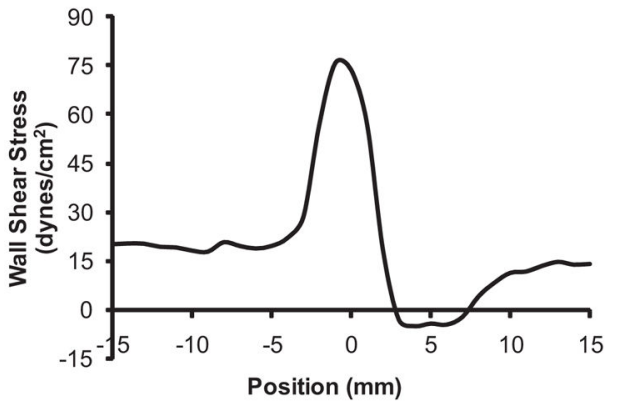

$\mathrm{E}$

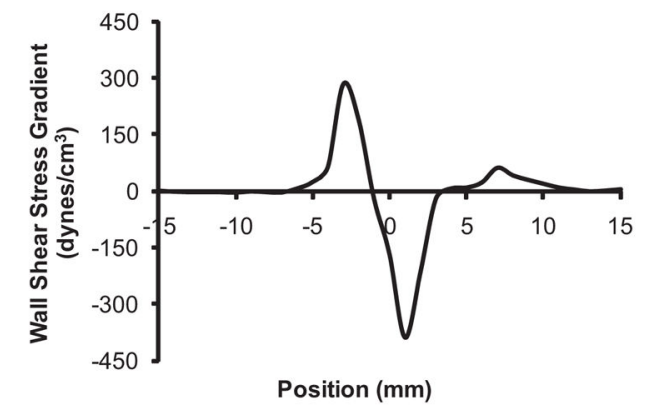

Figure 1.

Asymmetric stenosis model. (A) Model flow regions, including the inlet, proximal, peak, recirculation and distal regions. The length of each region is indicated approximately. (B) Perfusion flow loop diagram including individual vented reservoirs, a low pulsatility peristaltic pump, custom built dampeners and the in vitro models. The setup was placed on the bench, included a hot plate and a light microscope equipped with a CCD camera. (C) Representative images of flow profiles in the recirculation region at a Reynold number of 165 as acquired during photochromic molecular flow visualization studies. (D) Average wall shear stress magnitude values on the stenosis side measured from flow visualization and (E) corresponding spatial wall shear stress gradient. 


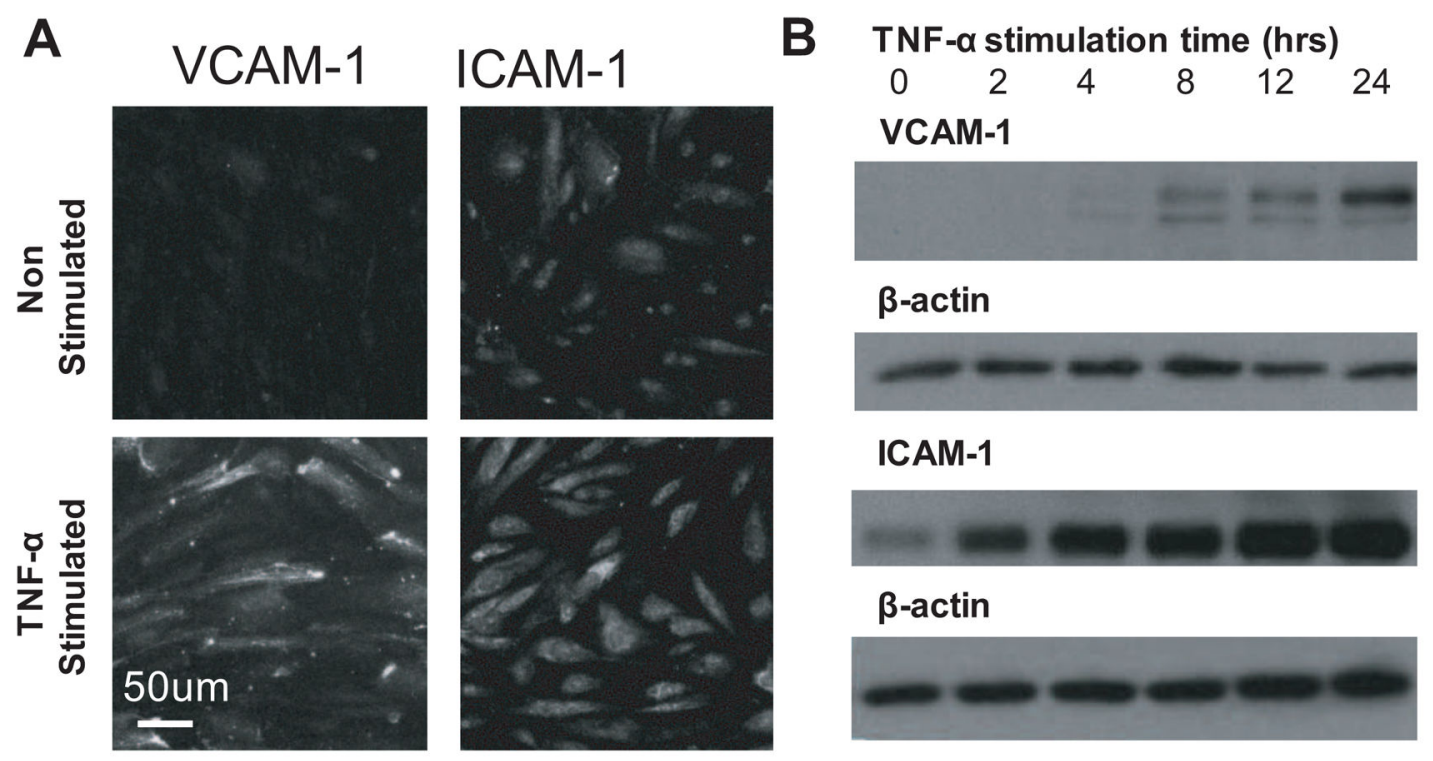

Figure 2.

Endothelial cell adhesion molecules expression. (A) Confocal images showing endothelial cell upregulation of ICAM-1 and VCAM-1 upon stimulation with TNF-a. (B) Western blotting results showing the dependency in time for ICAM-1 and VCAM-1 upregulation due to TNF-a using $\beta$-actin as a loading control. 
TNF- $\alpha$ Stimulated 24 hrs - No Stimulation for $1 \mathrm{hr}$

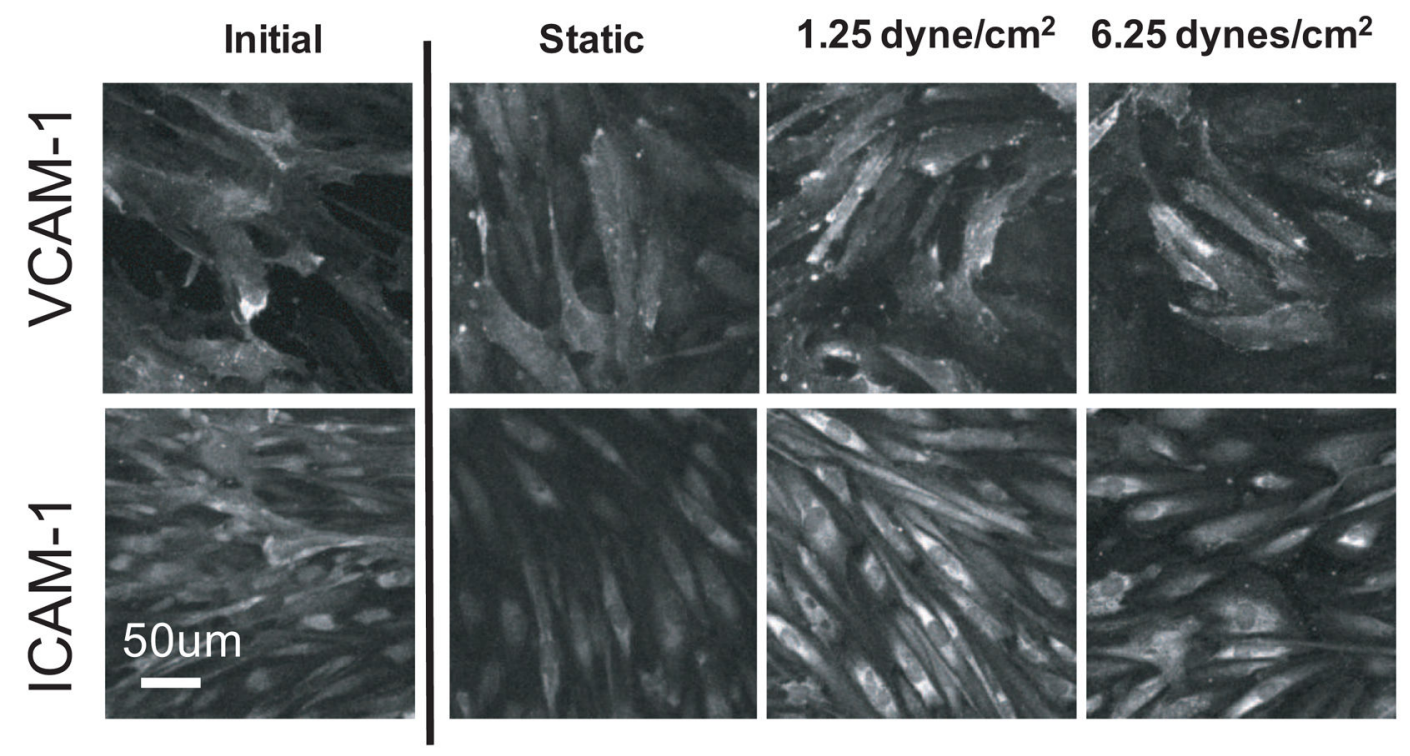

Figure 3.

Expression of cell adhesion molecules ICAM-1 and VCAM-1 following exposure to TNF-a as observed using confocal microscopy. Initial levels after $24 \mathrm{hrs}$ of TNF-a stimulation are shown, along with the expression after TNF- $\mathrm{a}$ was removed for $1 \mathrm{hr}$, under static conditions, low $\left(1.25 \mathrm{dyne} / \mathrm{cm}^{2}\right)$ and high $\left(6.25 \mathrm{dynes} / \mathrm{cm}^{2}\right)$ wall shear stresses. 

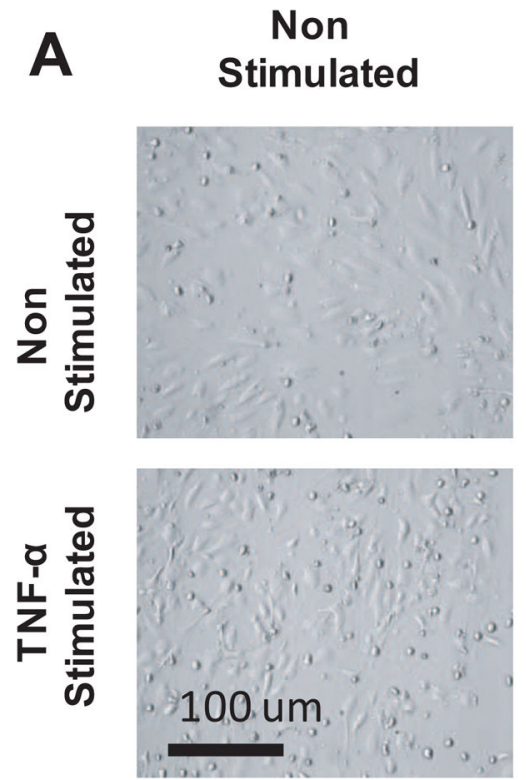

ATRA Stimulated
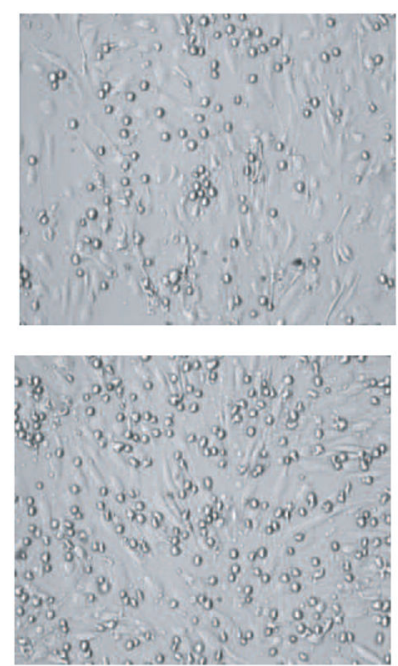

B

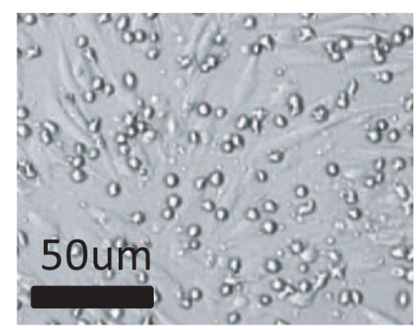

C

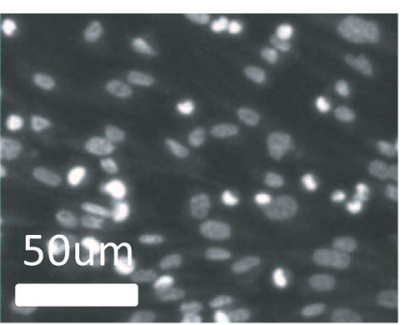

Figure 4.

(A) Representative microscopic images showing the effect of ATRA differentiation and TNF-a stimulation, (B) microscopic and (C) confocal images showing adhesion location mostly between endothelial cells. 

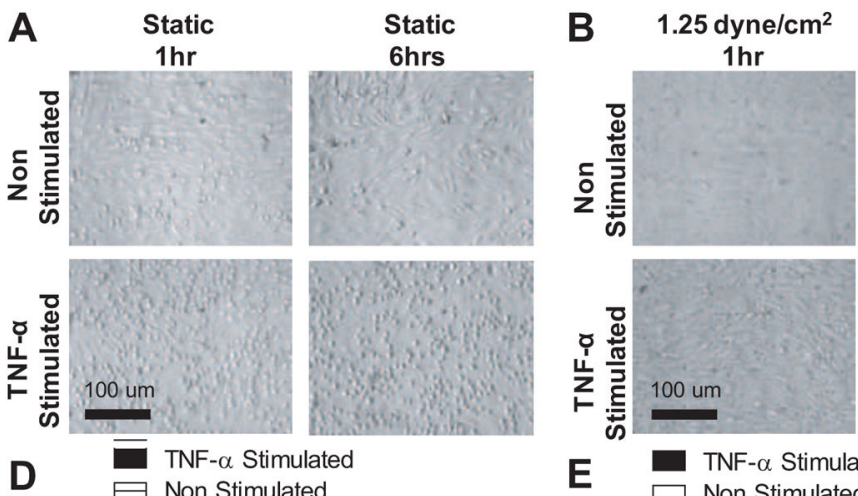

1.25 dyne/cm ${ }^{2}$

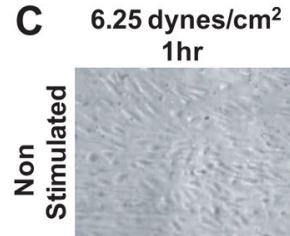

6.25 dynes $/ \mathrm{cm}^{2}$
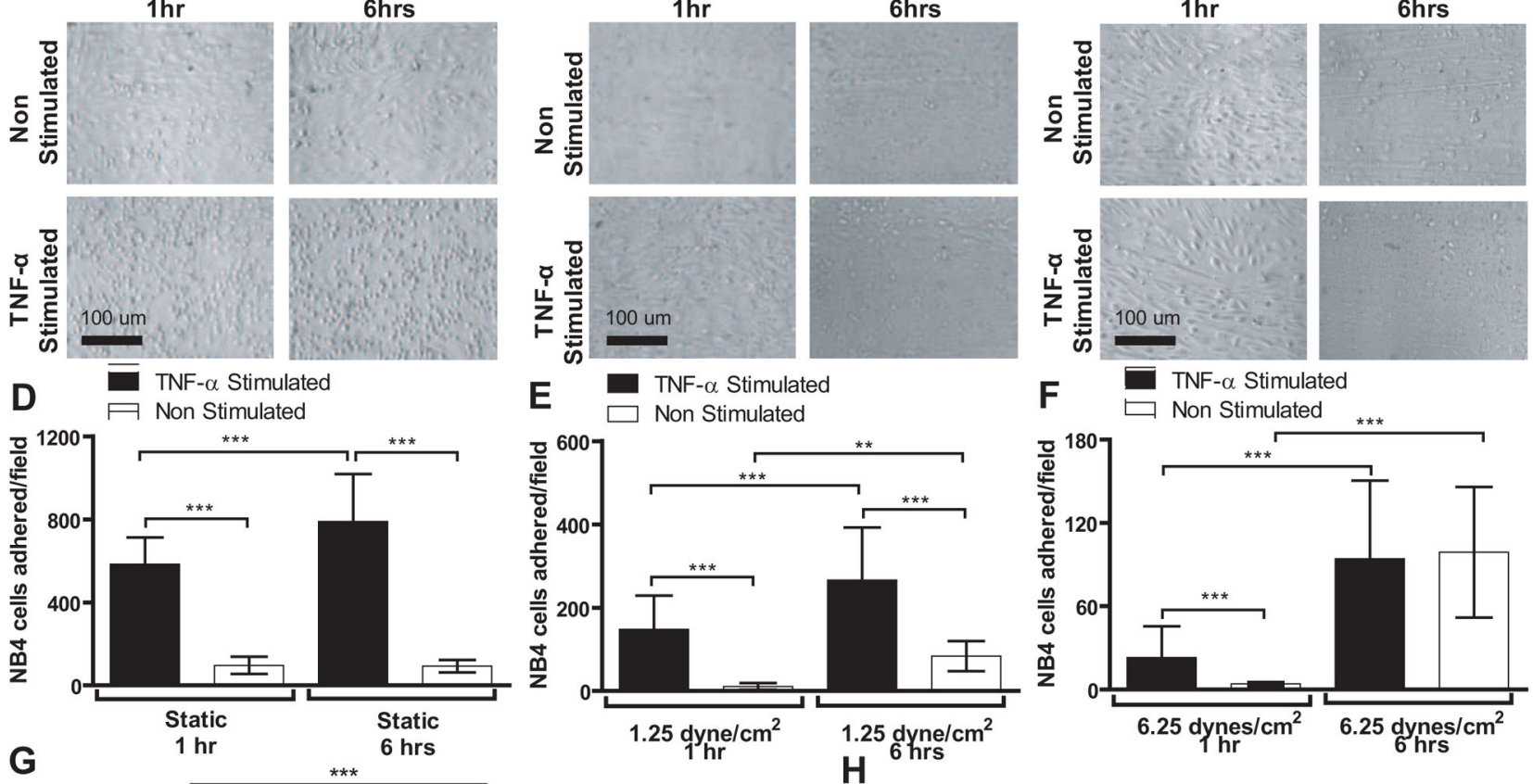

F $\square$ TNF- $\alpha$ Stimulated
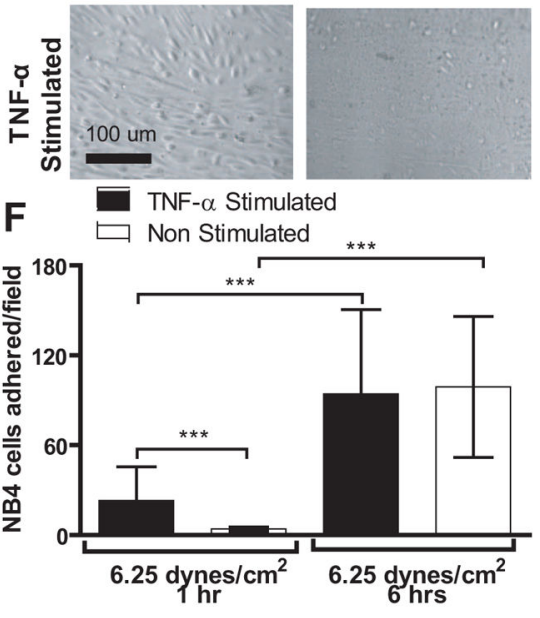

G
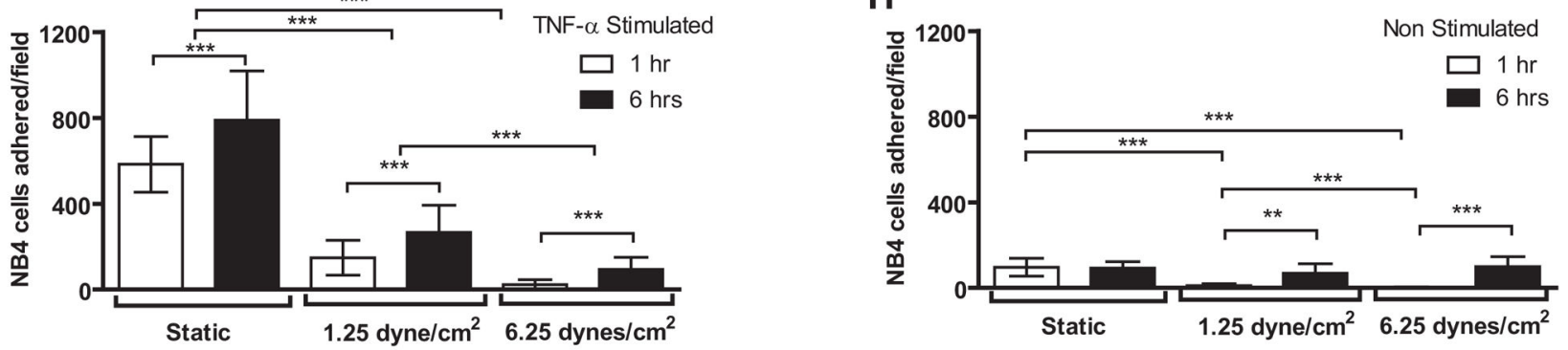

Figure 5.

Flow magnitude and time effect on adhesion. Representative microscopic images $(\mathrm{A}-\mathrm{C})$ and quantified NB4 cells adhesion on HAECs data (D-F) for static (A,D), $1.25 \mathrm{dyne} / \mathrm{cm}^{2}(\mathrm{~B}, \mathrm{E})$ and 6.25 dynes $/ \mathrm{cm}^{2}(\mathrm{C}, \mathrm{F})$ conditions. Comparison with respect to the time and shear magnitude for TNF-a stimulated $(\mathrm{G})$ and non stimulated cells $(\mathrm{H})$. (One-way ANOVA, $\mathrm{P}<0.01 * *$ and $\mathrm{P}<0.001 * * *)$. Data is expressed as mean \pm standard deviation, experiments were performed at least three times. 
TNF- $\alpha$ Stimulated 24 hrs - Static - Regional Analysis

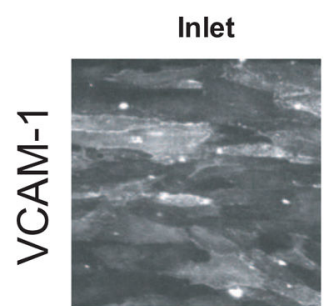

Proximal
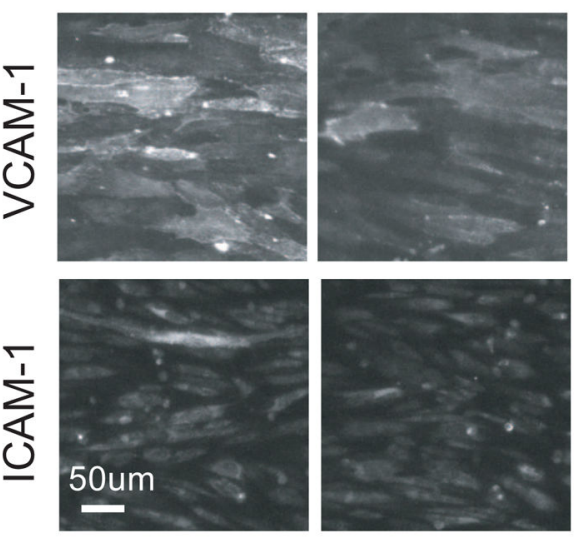

Peak
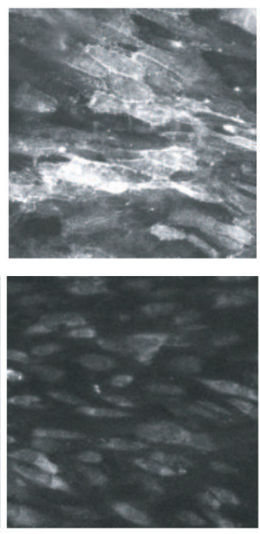

Recirculation
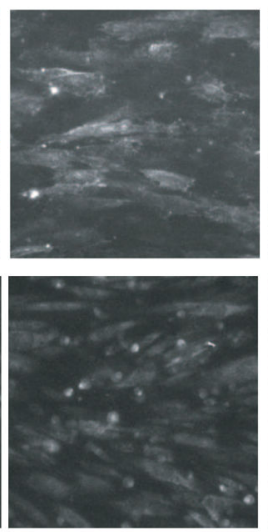

Distal
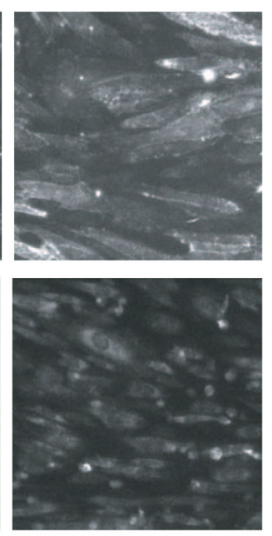

Figure 6.

Regional expression of cell adhesion molecules ICAM-1 and VCAM-1 in HAECs following exposure to TNF-a for 24 hrs grown in static conditions and after the adhesion assays, which were performed at low shear $\left(1.25 \mathrm{dyne} / \mathrm{cm}^{2}\right)$ for $1 \mathrm{hr}$, as observed using confocal microscopy. 

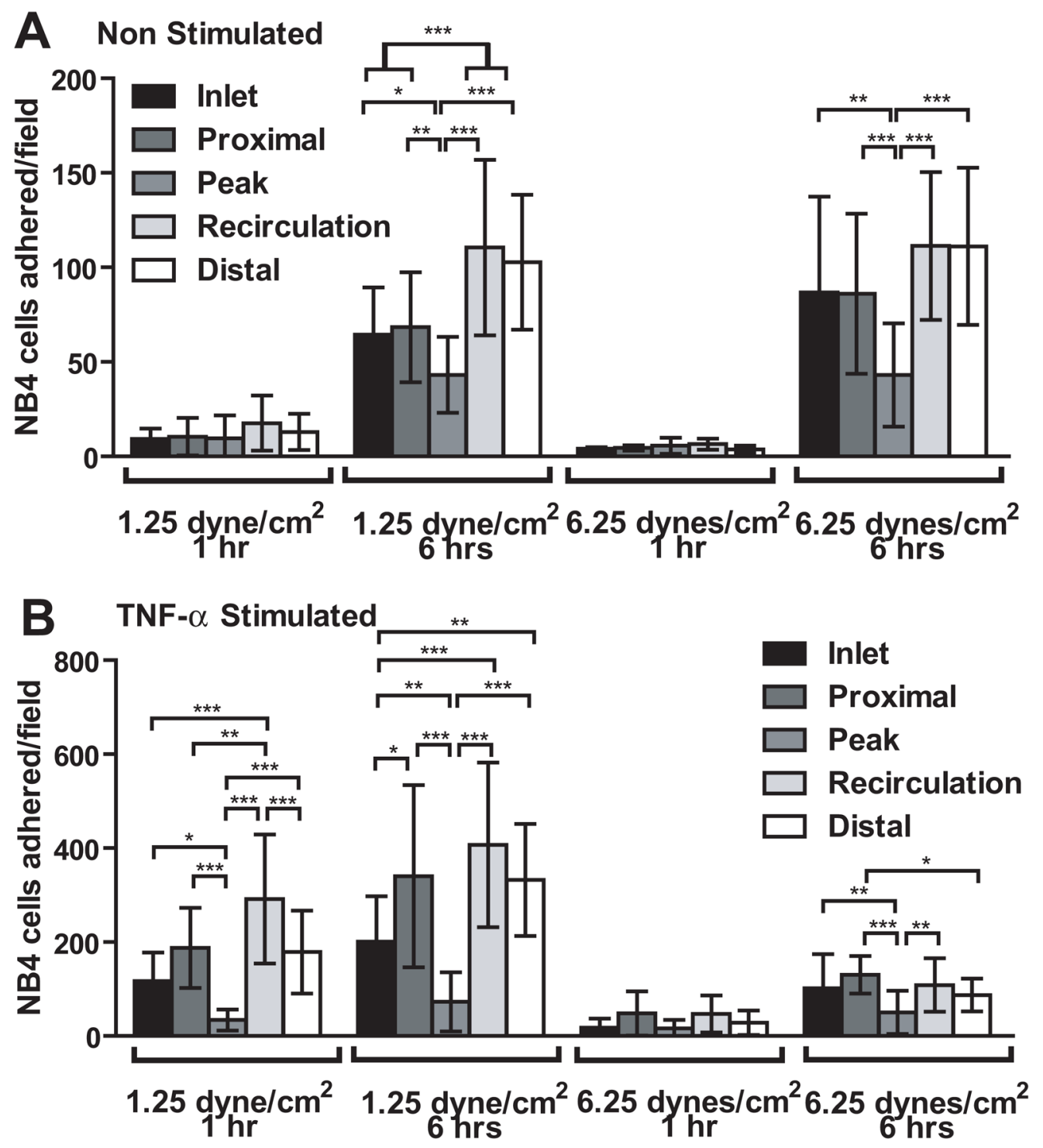

Figure 7.

Regional adhesion. NB4 cells adhesion to non stimulated HAECs (A) and TNF-a stimulated HAECs (B) under different wall shear stress conditions and for various times. (Two-way ANOVA, $\mathrm{P}<0.05 *, \mathrm{P}<0.01 * *$ and $\mathrm{P}<0.001 * * *)$ Data is expressed as mean \pm standard deviation, experiments were performed at least three times. 


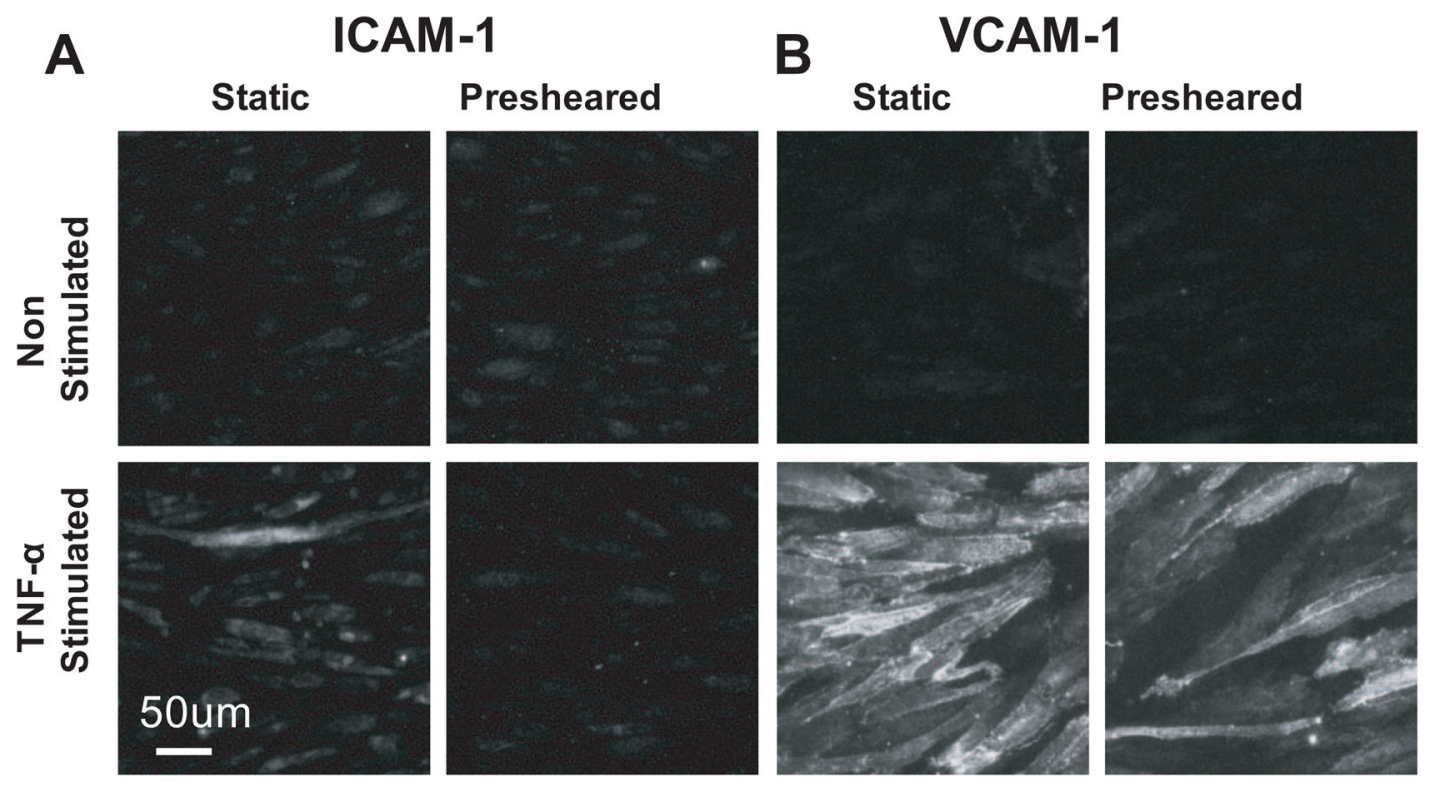

Figure 8.

Preshearing effect on the expression of cell adhesion molecules by non stimulated and TNFa stimulated HAECs. (A) ICAM-1 and (B) VCAM-1. 


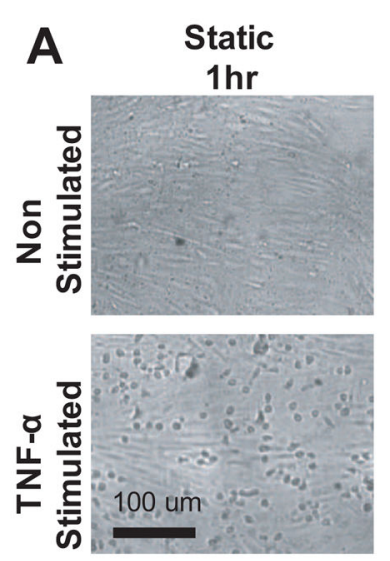

C
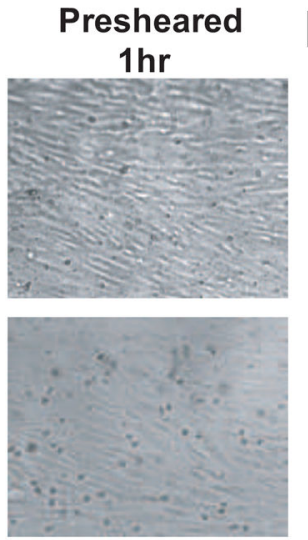

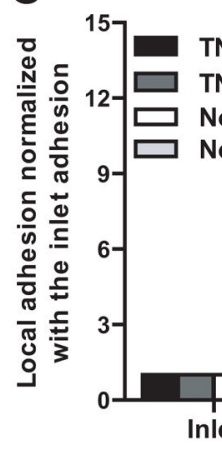

TNF- $\alpha$ Stimulated

TNF- $\alpha$ Stimulated Presheared

Non Stimulated

Non Stimulated Presheared

Figure 9.

Effect on NB4 adhesion of preshearing HAECs. (A) Representative microscopic images, (B) adhesion quantification and $(\mathrm{C})$ regional fold increase with respect to the inlet. (One-way and Two-way ANOVA, $\mathrm{P}<0.001 * * *)$ Data is expressed as mean \pm standard deviation, experiments were performed at least three times. 
TNF-a Stimulated 24 hrs - Presheared - Regional Analysis

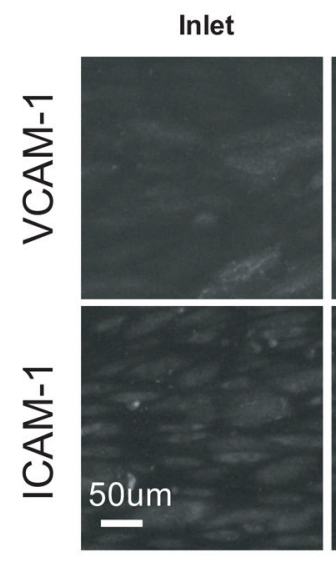

\begin{abstract}
Proximal
\end{abstract}
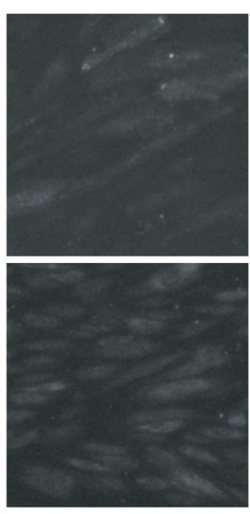

\begin{abstract}
Peak
\end{abstract}

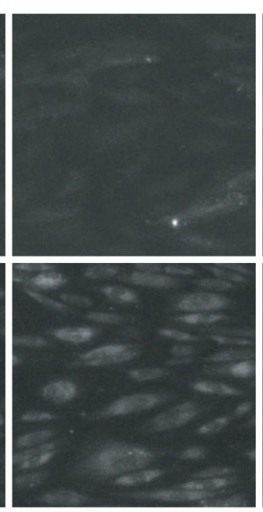

\begin{abstract}
Recirculation
\end{abstract}

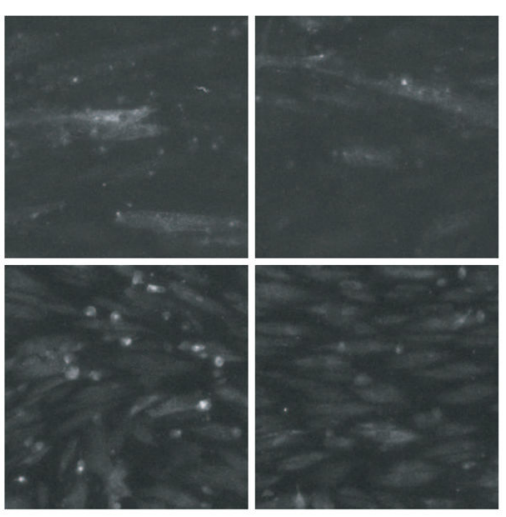

Figure 10.

Regional expression of cell adhesion molecules ICAM-1 and VCAM-1 following exposure to TNF-a for presheared cells during $24 \mathrm{hrs}$ and after the adhesion assays at low shear (1.25 dyne $/ \mathrm{cm}^{2}$ ) for $1 \mathrm{hr}$, as observed using confocal microscopy. 